\title{
Mitochondrial hyperpolarization and cytochrome-c release in microwave-exposed MCF-7 cells
}

\author{
Meric A. Esmekaya ${ }^{1}$, Ayşe G. Canseven ${ }^{1}$, Handan Kayhan², Mehmet Z. Tuysuz ${ }^{1}$, Bahriye Sirav ${ }^{1}$ \\ and Nesrin Seyhan ${ }^{1}$ \\ ${ }^{1}$ Department of Biophysics, Faculty of Medicine, Gazi University, Ankara, Turkey \\ ${ }^{2}$ Division of Hematology of the Department of Internal Medicine, Faculty of Medicine, Gazi University, Ankara, Turkey
}

\begin{abstract}
This study examines the effects of a 2.1-GHz WCDMA-modulated microwave (MW) radiation on apoptotic activity and mitochondrial membrane potential $\left(\Delta \Psi_{\mathrm{m}}\right)$ in MCF-7 cells. The cells were exposed to the MW at a specific absorption rate (SAR) of $0.528 \mathrm{~W} / \mathrm{kg}$ for 4 or $24 \mathrm{~h}$. The antiproliferative effect of MW exposure was determined by the MTT test. Cytochrome-c and p53 levels were determined by an ELISA method. The relative $\Delta \Psi_{\mathrm{m}}$ was analysed by JC-1 staining using flow cytometer. Apoptotic rate of the cells was measured by Annexin-V-FITC staining. All assays were performed after certain time of incubations ( $15 \mathrm{~min}-4 \mathrm{~h}$ ) following MW exposure. MW-exposed cells showed a significant decrease in viability when compared to unexposed cells. A significantly larger decrease was observed after longer exposure. The percentage of apoptotic cells, amount of cytochrome-c, and relative $\Delta \Psi_{\mathrm{m}}$ were significantly higher in MW-exposed cells. The percent of apoptotic cells and relative $\Delta \Psi_{\mathrm{m}}$ in $24 \mathrm{~h} \mathrm{MW}$-exposed group was significantly higher than those in $4 \mathrm{~h} \mathrm{MW}$-exposed group. However, no significant change was observed in p53 levels. These results demonstrated that exposure to 2.1-GHz WCDMA-modulated MW radiation caused hyperpolarization of mitochondria that in turn induced apoptosis in MCF-7 cells.
\end{abstract}

Key words: Microwave radiation - Mitochondrial membrane potential - Apoptosis - Cytochrome-c - p53

\section{Introduction}

Apoptosis can be initiated by at least two separable processes: one is an extrinsic pathway mediated by death receptors on the cell surface and the other is an instrinsic pathway involving release of cytochrome-c from mitochondria. Mitochondria play a crucial role in regulating cell death and they are essential in the intrinsic apoptotic pathway. A critical step in this pathway is the selective release of polypeptides from the mitochondrial intermembrane space into the cytoplasm in response to stress stimuli. After mitochondrial release of cytochrome-c which appears to be rapid and quantitative, mitochondria release AIF (apoptosis inducing factor) from the intermembrane space to the cytosol (Gold-

Correspondence to: Meric Arda Esmekaya, Department of Biophysics, Faculty of Medicine, Gazi University, 06510, Beşevler, Ankara, Turkey

E-mail: mericarda@yahoo.com stein et al. 2000). In the cytoplasm, cytochrome-c binds the Apaf-1 (apoptotic protease-activating factor 1) (Zou et al. 1997) which then undergoes a nucleoside triphosphatedependent conformational change and binds procaspase 9. This results in a molecular complex containing multiple Apaf- 1 and procaspase- 9 molecules called the apoptosome complex (Zou et al. 1999; Cain et al. 2000). Mitochondrial membrane potential $\left(\Delta \Psi_{\mathrm{m}}\right)$ is an important indicator of mitochondrial function and energization state. It plays an important role in ATP synthesis and ion homeostasis. It is also well known that mitochondria are a source of $\mathrm{Ca}^{2+}$ and regulate the levels of cytoplasmic $\mathrm{Ca}^{2+}$ concentration (Skárka and Ostádal 2004).

p53 is involved in both the intrinsic and the extrinsic pathways by initiating apoptosis. It has multiple functions. It acts as a transcription factor, promotes DNA repair, induces growth arrest or apoptosis and involved in the regulation of cell cycle, development, differentiation and chromosomal segregation (Oren and Rotter 1999; Haris 2003; Shankar and 
Srivastava 2007). Furthermore, it has been described as "the guardian of the genome" because of its role in conserving stability of the genome and is induced in response to a wide variety of stresses including DNA damage, hypoxia, and oncogene (Strachan and Read 1999). p53 can interact with transcriptionally activated genes and proteins that control mitochondrial membrane permeability and therefore can modulate the release of cytochrome-c, a component of the electron transport chain that is loosely bound to the outer leaflet of the inner mitochondrial membrane during apoptosis. p53 also regulates the balance between the glycolytic pathway and mitochondrial oxidative phosphorylation (Gogvadze et al. 2008).

In this study, estrogen receptor positive $(\mathrm{ER}+) \mathrm{MCF}-7$ human breast carcinoma cells were exposed to a $2.1 \mathrm{GHz}$ Wideband Code-Division Multiple Access (W-CDMA) microwave (MW) radiation for 4 or $24 \mathrm{~h}$. Possible changes in $\Delta \Psi_{\mathrm{m}}$ and apoptosis were assessed using flow cytometry which allows the analysis of heterogeneous cell populations. Cell viability was determined by the MTT (3 [4,5-dimethylthiazol2-yl]-2,5-diphenyltetrazolium bromide) test and levels of the apoptosis regulating proteins cytochrome-c and p53 were determined by the enzyme-linked immuno-assay (Elisa).

\section{Material and Methods}

\section{MCF-7 cell culture and MW exposure}

MCF-7 cells were cultured in $75 \mathrm{ml}$ culture flasks in Dulbecco's modified Eagle's medium (DMEM, supplemented with 10\% fetal bovine serum (FBS Invitrogen, Carlsbad, CA, USA), 2 mM glutamine (Sigma-Aldrich), 100 units/ $\mathrm{ml}$ of penicillin and $100 \mathrm{mg} / \mathrm{ml}$ of streptomycin. Cells were cultured in a humidified cell incubator at $37^{\circ} \mathrm{C}$ under $5 \%$ $\mathrm{CO}_{2}$ and $95 \%$ air. Before the experiment, they were plated at a density of $1 \times 10^{5}$ cells/well in 24-well culture plates. The exposure system consisted of a vector signal generator (Rohde \& Schwarz, Munich, Germany; SMBV 100 A, $9 \mathrm{kHz}-3.2 \mathrm{GHz}$ ) and a horn antenna (ETS-Lindgren, St Louis, MO, USA) placed inside a conventional humidified incubator (Nuve, Ankara, Turkey) at $37^{\circ} \mathrm{C}$ with the emitting end facing up. Cultured MCF-7 cells in a 24-well plate were placed above the horn antenna. MCF-7 cells were exposed to $2.1-\mathrm{GHz} \mathrm{W}$-CDMA radiation or sham-exposed for 4 or $24 \mathrm{~h}$. Control cells were sham-exposed, i.e., placed in the exposure setup for the same amount of time with the signal generator turned off.

Specific absorption rate (SAR) is defined as the rate of absorbed non-ionizing energy by unit mass of biological tissue and can be calculated as: $S A R=s\left|E^{2}\right| / r$; where $s$ is the electrical conductivity of tissue, $\mathrm{E}$ is the RMS electric field and $\mathrm{r}$ is the tissue density. The relation between incident power density
$\left(\mathrm{P}_{\mathrm{d}}=\mathrm{E}^{2} / 377\right)$ and SAR may be also shown as $\mathrm{P}_{\mathrm{d}}=(\mathrm{rSAR}) /$ (377s). The distribution of SAR in cell sample was computed by SEMCAD x (Schmid \& Partner Engineering AG, Zurich, Switzerland) which is a three dimensional (3-D) commercial full-wave simulation software solving Maxwell's equations based on the Finite-Difference Time-Domain (FDTD) method (Yee 1992). Numerical models for the DMEM medium inside 24-well microtiter plates were used to assess peak SAR values averaged over $10 \mathrm{~g}$ of tissue at $2.1 \mathrm{GHz}$. The plates were filled with $1 \mathrm{ml}$ of the medium (DMEM) with relative dielectric constant $\left(\mathrm{e}_{\mathrm{r}}\right)$ of 75 and electric conductivity $(\sigma)$ of $2.2 \mathrm{~S} / \mathrm{m}$ at $2.1 \mathrm{GHz}$. They were consisted of 24 cylindrical polystyrene tubes. Each tube had $8 \mathrm{~mm}$ inner diameter, $9 \mathrm{~mm}$ outer diameter and $18 \mathrm{~mm}$ in height (Zeni et al. 2012).

Conformal FDTD and grading mesh algorithm was used to reduce the number of voxels and computational time in simulation (Yee et al. 1992). The minimum and maximum grid steps were $8.2 \times 10^{-5}$ and $6.3 \times 10^{-3}$ respectively. The simulation consisted of 70.17 million voxels. The Perfectly Matched Layer (PML) absorbing boundary condition was used as a means to truncate FDTD lattices (Berenger 1994). SAR value was obtained by normalizing antenna input power to 1 Watt. Peak spatial SAR averaged over $10 \mathrm{~g}$ tissue was calculated to be $0.528 \mathrm{~W} / \mathrm{kg}$ at $2.1 \mathrm{GHz}$. The simulated SAR distribution for cell cultures exposed to MW radiation was given in Figure 1A. Hot points exceeding $2 \mathrm{~W} / \mathrm{kg}$ were also given in Figure 1B. The signal waveform was observed by using an oscilloscope. The radiation intensity within the incubator on the cells surface was measured to be $0.120 \mathrm{~mW} /$ $\mathrm{cm}^{2}$ by an isotropic probe (Rohde \& Schwarz) and a handheld spectrum analyzer (R\&S FSH4, Rohde \& Schwarz). The ambient magnetic field level was $1.46 \mathrm{mG}$.

\section{In vitro cytotoxicity assay}

The effect of MW radiation on viability of MCF-7 cells in the 24-microwell plates was determined using tetrazolium dye MTT (3[4,5-dimethylthiazol-2-yl]-2,5-diphenyltetrazolium bromide, Invitrogen, Carlsbad, CA, USA). This assay was based on the capacity of cells to reduce 3-(4,5-dimethylthiazol-2yl)-2,5-diphenyltetrazolium bromide to formazan. Briefly; after 4 or 24 h of MW exposure, cells were plated onto 96-well microtiter plates at a concentration of $5 \times 10^{4}$ cells /well in $100 \mu$ l culture medium and incubated with MTT $(0.5 \mathrm{mg} / \mathrm{ml})$ for $4 \mathrm{~h}$ at $37^{\circ} \mathrm{C}$. The incubation was followed by formation of purple formazan salts crystals by a NADP/NA$\mathrm{DPH}$ dependent process. The samples were then incubated overnight in a humidified atmosphere $\left(37^{\circ} \mathrm{C}, 5 \% \mathrm{CO}_{2}\right)$. The solubilised formazan product was quantified spectrophotometrically using an ELISA reader (Molecular Devices, Sunnyvale, CA, USA). The cell viability of MW-exposed cells was calculated relative to that of sham-exposed controls. (The viability results of MW-exposed cells were presented 
as percent of the viability of sham-exposed cells, considering sham-exposed cells had $100 \%$ cell viability).

\section{ELISA assay of cytochrome-c and p53}

The level of p53 protein was determined by an enzymelinked immuno-assay (ELISA) method. Cells were exposed to the 2.1-GHz MW radiation for 4 or $24 \mathrm{~h}$ and then cell culture supernatants were immediately aliquoted and stored frozen at $-20^{\circ} \mathrm{C}$ until assay. Prior to assay, the samples were brought to room temperature and mixed gently. The remaining steps were carried out according to the instructions supplied by the manufacturer of the assay kit. The absorbance of each microwell was read using $450 \mathrm{~nm}$ as the primary wavelength on an ELISA reader (Molecular Devices, Sunnyvale, CA, USA). and then p53 concentrations in both MW and sham-exposed samples were determined by interpolating from a standard curve.

The amount of cytochrome-c in MCF-7 cells was measured using an Elisa kit (Human Cyctochrome-c Platinium ELISA Kit, eBioscience). After MW radiation exposure, cells were centrifuged at $174 \times g$ for $15 \mathrm{~min}$ and pellets were washed once in cold phosphate buffered saline (PBS). The cell pellets were then re-suspended in lysis buffer and incubated for $1 \mathrm{~h}$ at room temperature. Afterwards, cells were centrifuged at $200 \times g$ for $15 \mathrm{~min}$. Then, the supernatants were diluted in assay buffer and the resulting supernatants were collected for cytochrome-c measurements. The remaining steps were carried out according to the manufacturer's instructions. The optical density of each well was measured at $450 \mathrm{~nm}$ using a ELISA reader (Molecular Devices, Sunnyvale, CA, USA). Cytochrome-c levels were calculated from a standard curve based on reference standards.

\section{Apoptosis assay}

Annexin V-FITC conjugated protein binds to phosphatidylserine which is an early apotosis marker. Cells stained with propidium iodide (PI) indicated necrotic cells where the cell membrane has been totally compromised. After 4 or $24 \mathrm{~h}$ MW exposure, MCF-7 cells were washed with PBS by gentle shaking and pipetting up and down. Cells were resuspended in $200 \mu \mathrm{l}$ of a binding buffer $(1 \times)$ provided by the manufacturer (eBioscience). $5 \mu \mathrm{l}$ of Annexin-V-FITC was added to $195 \mu \mathrm{l}$ of cell suspension. The suspension was mixed and incubated for $10 \mathrm{~min}$ at room temperature. The cells were washed in $200 \mu \mathrm{l}$ binding buffer $(1 \times)$ and resuspended in $190 \mu \mathrm{l}$ binding buffer $(1 \times)$. Then, $10 \mu \mathrm{l} \mathrm{PI}(20 \mu \mathrm{g} /$ $\mathrm{ml}$ ) was added. Samples were analyzed by a FacsCalibur Flow Cytometer with Cell Quest software (Becton-Dickinson, San Jose, CA, USA).

\section{Determination of relative $\Delta \Psi m$}

The relative $\Delta \Psi_{\mathrm{m}}$ was determined by JC-1 $\left(5,5^{\prime}, 6,6^{\prime}\right.$ tetrachloro-1,1',3,3'- tetraethylbenzimidazolcarbocyanine iodide) staining using a flow cytometer. JC-1 is frequently used to measure $\Delta \Psi_{\mathrm{m}}$. If the membrane is depolarized, JC-1 cannot access the mitochondrial matrix. At low $\Delta \Psi_{\mathrm{m}}$, JC-1 remains in monomeric form and exhibits a green color. However, at high $\Delta \Psi_{\mathrm{m}}$, JC-1 forms J-aggregates and exhibits a red fluorescence. Relative mitochondrial hyperpolarization is indicated by an increase in the red/green fluorescence intensity ratio. Following MW/sham exposures for 4 or $24 \mathrm{~h}$, samples were stained for JC-1 (Cayman Chemical, Ann Arbor, MI, USA). The remaining steps were carried out according to the instructions supplied by the manufacturer. Mean fluorescence intensity of samples were measured by flow cytometer (Becton-Dickinson, San Jose, CA, USA). Change in $\Delta \Psi_{\mathrm{m}}$ was estimated by calculating the ratio of red and green fluorescence (Struckhoff et al. 2004).

\section{Statistical analysis}

All experiments were performed under blind conditions. The data for each group was expressed as mean \pm standard deviation (SD) of five independent experiments. Five in-
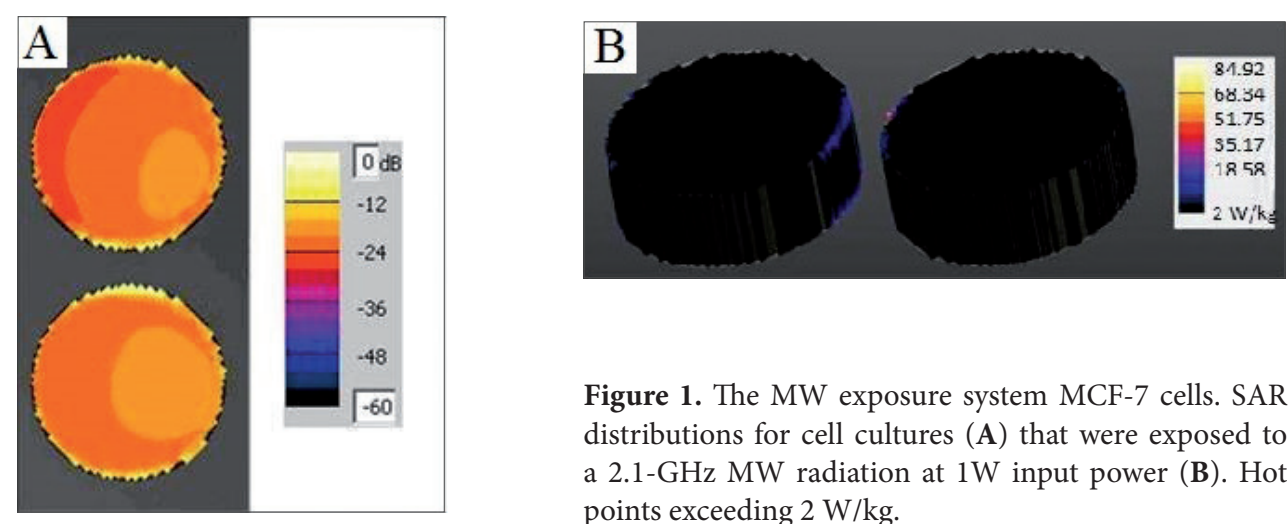

Figure 1. The MW exposure system MCF-7 cells. SAR distributions for cell cultures (A) that were exposed to a 2.1-GHz MW radiation at $1 \mathrm{~W}$ input power (B). Hot points exceeding $2 \mathrm{~W} / \mathrm{kg}$. 
dependent experiments were performed in each treatment group and three samples were measured and averages of the three measurements were used in data analysis. Statistical analyses were carried out using the Mann-Whitney $U$ and Kruskal Wallis tests using SPSS. A difference at $p<0.05$ was considered to be statistically significant.

\section{Results}

\section{$M W$ radiation inhibits MCF-7 cell proliferation}

To determine the cytotoxicity of the MW radiation, MTT assay was used. The viability of MW-exposed MCF-7 cells was given as percent of sham-exposed cells by assuming that sham-exposed cells had a viability of $100 \%$. The viability of MW exposed cells were decreased significantly $(p<0.05)$ in all exposure periods when compared to sham-exposed cells (Figure 2A).

\section{$M W$ radiation increased apoptotic activity}

The MCF-7 cells were exposed to MW radiation and stained for Annexin-V-FITC and PI for flow cytometry analysis. Annexin-V FITC positive cells were considered as apop-

\section{A}

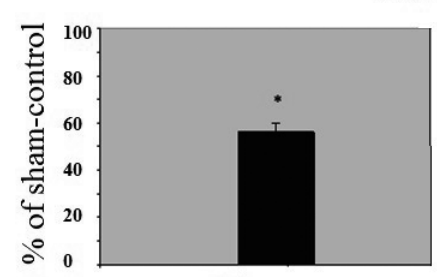

$4 \mathrm{~h}$ MW
Cell Viability

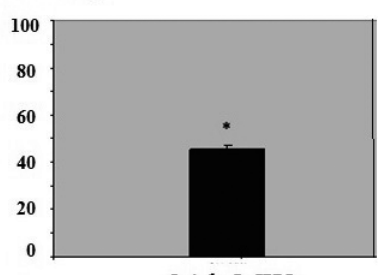

24 h MW
B

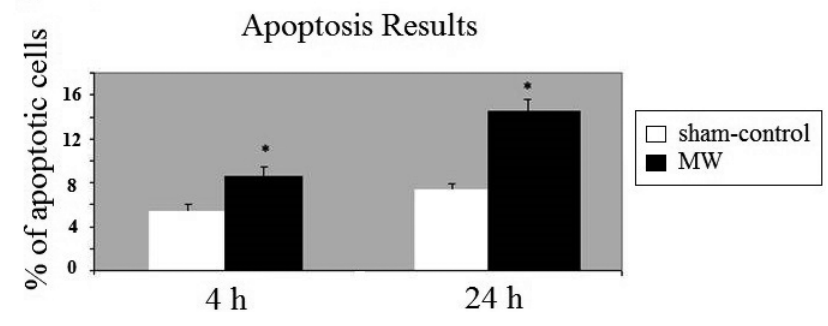

Figure 2. A. Measurement of cellular viability of 4 or 24 h MWexposed cells (\% of sham-exposed cells). B. Percentage of Annexin$\mathrm{V}$ positive cells after 4 or $24 \mathrm{~h}$ exposure to a 2.1- GHz MW radiation. Cells were analysed by flow cytometry with Annexin-V and PI to determine the percentage of apoptosis. Data of each group was expressed as mean \pm standard deviation (SD) of five independent experiments. Three samples were measured and analyzed for each experiment. ${ }^{*}$ indicated statistically significant at $p<0.05$ compared to control. Vertical bars indicated percent of cells SD in each group. totic. The percantage of Annexin-V FITC positive cells were significantly higher $(p<0.05)$ in the 4 and $24 \mathrm{~h} \mathrm{MW-}$ exposed groups when compared with sham-exposed cells (Figure 2B).

\section{MW irradiation increased $p 53$ and cytochrome-c levels}

The levels of p53 protein in both MW- and sham-exposed cells were assessed by ELISA method. The results in U/ $\mathrm{ml}$ were presented in Figure 3A. As seen in the figure, no significant difference $(p>0.05)$ in p53 levels between MW- and sham-exposed cells were detected. Cytochrome-c levels were significantly higher $(p<0.05)$ in both 4 and $24 \mathrm{~h}$ MW-exposed MCF-7 cells when compared with respective sham-exposed cells (Figure $3 \mathrm{~B}$ ). The protein levels of cytochrome-c were $0.8 \pm 0.07$ and $1.21 \pm 0.15 \mathrm{ng} /$ $\mathrm{ml}$ in 4 and $24 \mathrm{~h}$ sham-exposed cells, respectively. On the other hand, cytochrome-c levels were $1.42 \pm 0.17$ and 1.56 $\pm 0.11 \mathrm{ng} / \mathrm{ml}$ in cells exposed to $\mathrm{MW}$ radiation for 4 and $24 \mathrm{~h}$, respectively.

\section{Mitochondrial hyperpolarization due to $M W$ radiation exposure}

The $\Delta \Psi_{\mathrm{m}}$ was estimated by calculating the ratios of red/ green fluorescence. Results are presented in Figure 4B. As seen in the figure, the ratio of red/green fluorescence was significantly increased $(p<0.05)$ in the 4 -h MW-exposed cells when compared to sham-exposed cells. Similarly, red/ green fluorescence ratio was higher in the 24-h exposed cells. Increase in red/green fluorescence ratio was exposure time-dependent. These results showed that MW radiation at a frequency of $2.1 \mathrm{GHz}$ induced an increase in $\Delta \Psi_{\mathrm{m}}$, so the cells became more hyperpolarized (Figure 4A) when exposed to the MW radiation.

\section{Discussion}

The literature investigating the effects of MW on biological systems is inconsistent. Exposure to a 900-MHz MW radiation increased apoptotic activity of rat brain cells (Joubert et al. 2008). Similarly, apoptotic rates of Chinese hamster V-79 cells were increased significantly after a 15 min exposure to a $2.45-\mathrm{GHz}$ MW radiation (Ballardin et al. 2011). MW radiation also increased caspase activities in the rat thyroids (Esmekaya et al. 2011). In another study, mouse neuroblastoma cells in either proliferating or differentiated state were exposed to a Global System for Mobile Communications (GSM) basic talk mode signal or CW MW signal of $935 \mathrm{MHz}$ for $24 \mathrm{~h}(2 \mathrm{~W} / \mathrm{kg})$. No significant change in apoptotic levels of murine neuroblastoma cells was detected (Moquet et al. 2008). Merola et al. (2006) failed to find any evidence that 
a 900-MHz modulated MW radiation induced alterations in either apoptosis or cellular proliferation. Zeni et al. (2012) exposed rat PC12 cells to a 1950-MHz Universal Mobile Telecommunications System (UMTS) MW radiation. Despite a high SAR value $(10 \mathrm{~W} / \mathrm{kg})$ was used in the experiment, they could not observe any significant difference in both cell viability and apoptosis between control and MW-exposed cells. On the other hand, results of the present experiment showed that MW radiation at $2.1 \mathrm{GHz}$ had an exposure duration- dependent inhibitory effect on cell proliferation. Moreover, percentage of Annexin-V positive cells was higher in MW-exposed cells when compared to sham-exposed cells.

Mitochondria play an important role in apoptosis. Dysfunction of mitochondria may lead to an increase in permeability of inner mitochondrial membrane and rupture of the outer membrane causing release of cytochrome-c into the cytoplasm (Green and Kroemer 2004). Cytochrome-c release is one of the important steps in mitochondrial induced apoptosis (Kim et al. 2006). We observed a significant increase in cytochrome-c levels in MW-exposed cells. There are conflicting results in the literature on $\Delta \Psi_{\mathrm{m}}$ and cytochrome-c release
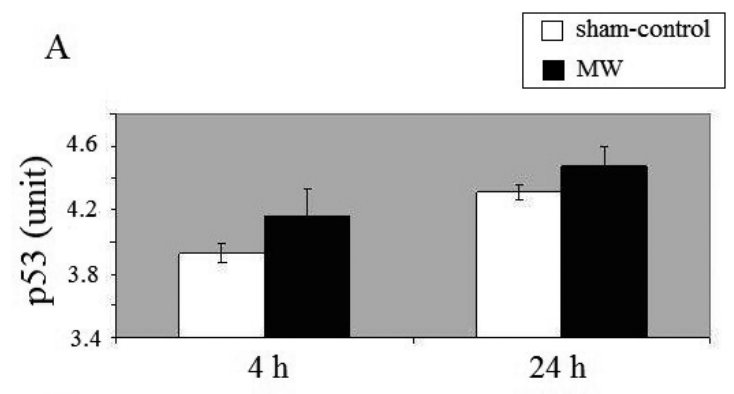

B

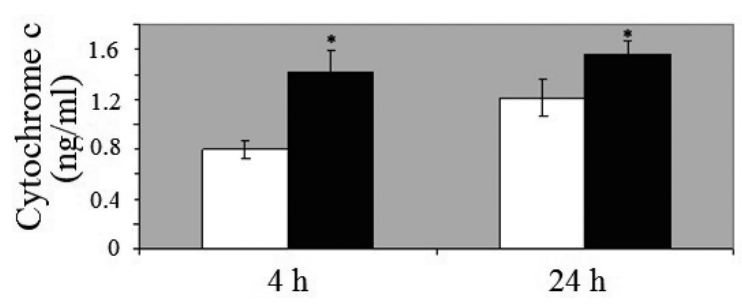

Figure 3. A. p53 protein levels in 4- and 24-h MW- and shamexposed cells. The data for each group was expressed as mean \pm standard deviation (SD) of five independent experiments. Five independent experiments were performed in each group and three samples were measured and analyzed for each experiment. ${ }^{*}$ indicated statistically significant at $p<0.05$ compared to comtrol. B. The levels of cytochrome-c in 4- and 24-h MW- and sham-exposed cells. Data for each group was expressed as mean \pm standard deviation (SD) of five independent experiments. Five independent experiments were performed in each group and three samples were measured and analyzed for each experiment. ${ }^{*}$ indicated statistically significant at $p<0.05$ compared to control. from the mitochondria. Some of the studies reported that release of cytochrome-c was related to a decrease in $\Delta \Psi_{\mathrm{m}}$. However, other studies noted that release of this protein occured after a transient increase in $\Delta \Psi_{\mathrm{m}}$ (Facompré et al. 2000; Castedo et al. 2002).

Our result demonstrated that MW radiation caused an increase in $\Delta \Psi_{\mathrm{m}}$ in MCF-7 cells. We believed that the increase in apoptotic rate in $\mathrm{MW}$-exposed cells was related to the increase in $\Delta \Psi_{\mathrm{m}}$. Most of the studies in the literature reported induction of apoptotic cell death due to reduction of $\Delta \Psi_{\mathrm{m}}$ (depolarization of mitochondria). However, some recent studies showed that apoptosis may be resulted from increased $\Delta \Psi_{\mathrm{m}}$ (Kadenbach et al. 2004). Mitochondrial hyperpolarization was shown in some types of cancer cells in literature. As $\Delta \Psi_{\mathrm{m}}$ increases, electrochemical potential is not consumed by ATP synthase (Kadenbach et al. 2004, 2011). FoF1-ATPase utilizes extruded protons to synthesize ATP and then the protons reenter the inner membrane to prevent hyperpolarization. Dysfunction of FoF1-ATPase may lead to hyperpolarization of mitochondria (Iijima et al. 2003).

p53 is the most commonly mutated gene in approximately half of all human cancer cells (Hollstein et al. 1991). It is involved in the induction of cell cycle regulation, development, and differentiation. Inactivation or loss of p53 has been associated with loss of cellular apoptotic responses. The role of $\mathrm{p} 53$ in apoptosis has been showed in both in vitro and in vivo studies (Yu 2006). A correlation between p53 gene mutation and p53 levels in tumours has been reported (Bennett et al. 1991). High p53 levels were observed in many types of human neoplasias including breast cancer (Vojtěsek and Lane 1991). Our study showed that p53 expression did not change significantly after MW radiation exposure. This result demonstrated that increase in the apoptotic rates of MCF-7 cells were not due to a change in p53 levels. Similar to our study, Hirose et al. (2006) exposed IMR-90 fetal lung fibroblasts to CW or W-CDMA-modulated MW radiation at $2.1425 \mathrm{GHz}$ for $28 \mathrm{~h}$. The SAR was $80 \mathrm{~mW} / \mathrm{kg}$. No significant change in expression levels of phosphorylated p53 at serine 15 or total p53 was seen between MW- and sham-exposed cells. Different from our study, they did not observe any significant increase in apoptotic activities in MW-exposed fibroblast cells. In another study, Nikolova et al. (2005) exposed mouse embryonic stem (ES) derived neural progenitor cells to a combination of 50-Hz ELF (extremely low frequency) field and 1.71-GHz MW radiation. They found no significant effect on p53 mRNA level in the cells. However, the authors reported that EMF exposure could affect at transcript level genes related to apoptosis and cell cycle control.

The present study investigated whether exposure to a 2.1-GHz W-CDMA-modulated MW radiation affects the apoptotic rates of ER+ MCF-7 human breast carcinoma cells which have high metabolic rates. Relative $\Delta \Psi_{\mathrm{m}}$ was also studied. We found that W-CDMA-modulated MW radia- 

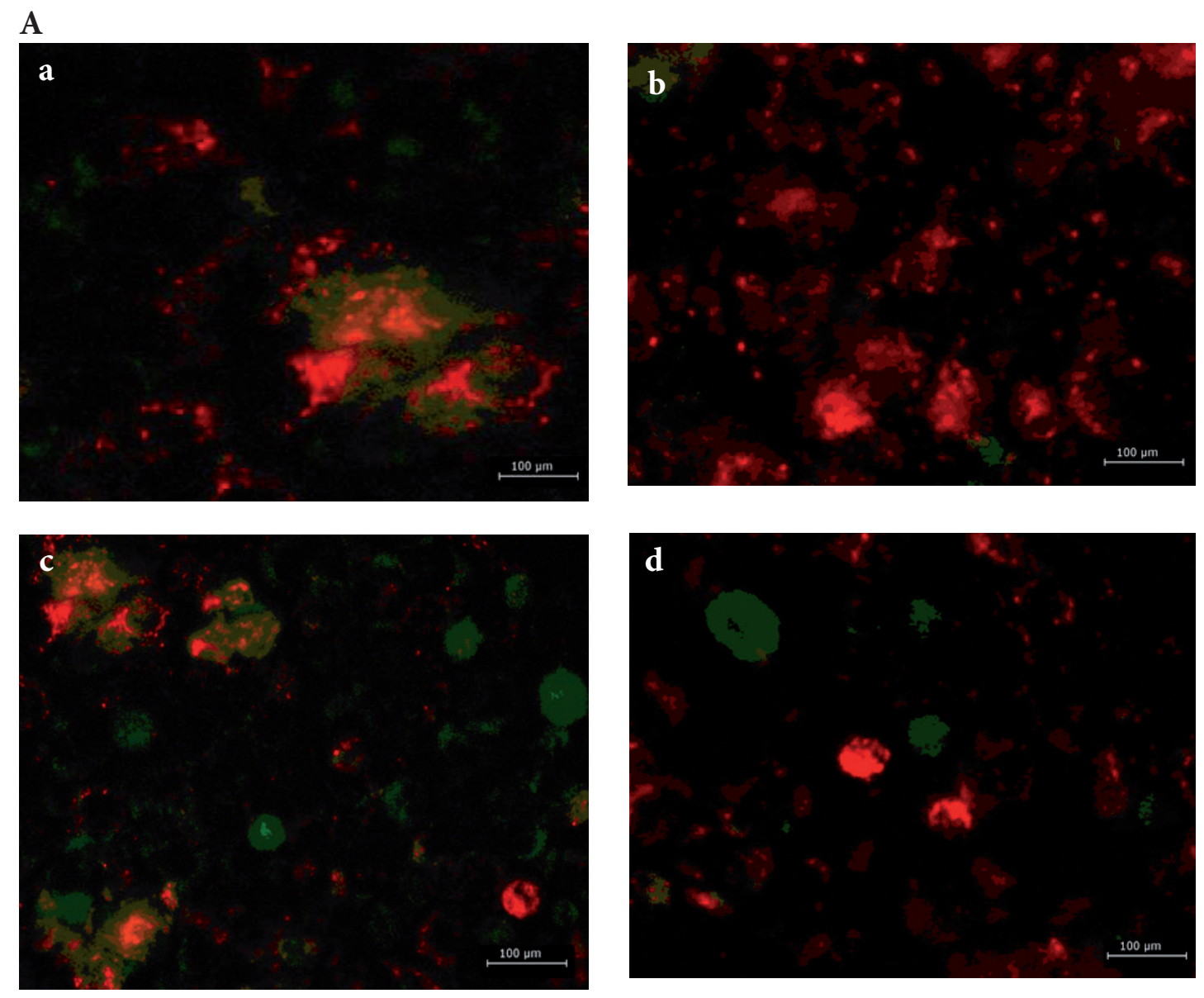

B

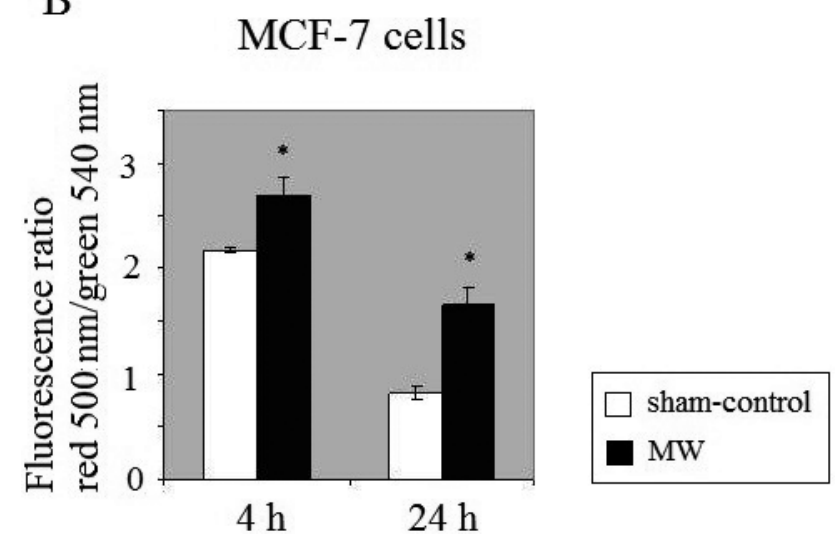

Figure 4. A. Fluorescence photographs of JC-1 staining in 4-h shamexposed (a) and 4-h MW-exposed (b), and 24-h sham-exposed (c) and 24-h MW-exposed (d) MCF-7 cells. Size scale $100 \mu \mathrm{m}$. B. Red/ green fluorescence ratio of $\Delta \Psi_{\mathrm{m}}$ measurement. Data for each group was expressed as mean \pm standard deviation (SD) of five independent experiments. Five independent experiments were performed in each group and three samples were measured and analyzed for each experiment. ${ }^{*}$ indicated statistically significant at $p<0.05$ compared to control.

tion at a SAR of $0.528 \mathrm{~W} / \mathrm{kg}$ induced hyperpolarization of mitochondria in MCF-7 cells. Moreover, hyperpolarization of mitochondria could cause an increase in the rate of apoptotic cell death and inhibition of MCF-7 cell proliferation.

Acknowledgement. This work was supported by the Research Funds of Gazi University (Project number: 01-2011-32).

\section{References}

Ballardin M., Tusa I., Fontana N., Monorchio A., Pelletti C., Rogovich A., Barale R., Scarpato R. (2011): Non-thermal effects of $2.45 \mathrm{GHz}$ microwaves on spindle assembly, mitotic cells and viability of Chinese hamster V-79 cells. Mutat. Res. 716, 1-9 https://doi.org/10.1016/j.mrfmmm.2011.07.009 
Bennett W. P., Hollstein M. C., He A., Zhu S. M., Resau J., Trump B. F., Metcalf R. A., Welsh A., Gannon J. V., Lane D. P., Haris C.C. (1991): Archival analysis of $\mathrm{p} 53$ genetic and protein alterations in chinese esophageal cancer. Oncogene 6, 1779-1784

Berenger J. P. (1994): A perfectly matched layer for the absorption of electromagnetic waves. J. Comput. Phys. 114, 185-200 https://doi.org/10.1006/jcph.1994.1159

Cain K., Bratton S. B., Langlais C. (2000): Apaf-1 oligomerizes into biologically active approximately $700-\mathrm{kDa}$ and inactive approximately 1. 4-MDa apoptosome complexes. J. Biol. Chem. 275, 6067-6070 https://doi.org/10.1074/jbc.275.9.6067

Castedo M., Ferri K., Roumier T., Métivier T., Zamzami D. N., Kroemer G. (2002): Quantitation of mitochondrial alterations associated with apoptosis. J. Immunol. Methods 265, 39-47 https://doi.org/10.1016/S0022-1759(02)00069-8

Esmekaya M. A., Seyhan N., Ömeroğlu S. (2010): Pulse modulated $900 \mathrm{MHz}$ radiation induces hypothyroidism and apoptosis in thyroid cells: A light, electron microscopy and immunohistochemical study. Int. J. Radiat. Biol. 86, 1106-1116 https://doi.org/10.3109/09553002.2010.502960

Facompré M., Wattez N., Kluza J., Lansiaux A., Bailly C. (2000): Relationship between cell cycle changes and variations of the mitochondrial membrane potential induced by etoposide. Mol. Cell Biol. Res. Commun. 4, 37-42 https://doi.org/10.1006/mcbr.2000.0251

Goldstein J. C., Waterhouse N. J., Juin P., Evan G. I., Gren D. R. (2000): The coordinate release of cytochrome c during apoptosis is rapid, complete and kinetically invariant. Nat. Cell Biol. 2, 156-162 https://doi.org/10.1038/35004029

Gogvadze V., Orrenius S., Zhivotovsky B. (2008): Mitochondria in cancer cells: what is so special about them? Trends Cell Biol. 18, 165-173 https://doi.org/10.1016/j.tcb.2008.01.006

Green D. R., Kroemer G. (2004): The pathophysiology of mitochondrial cell death. Science 305, 626-629 https://doi.org/10.1126/science.1099320

Haris C. C. (2003): P53 tumor suppressor gene: from the basic research laboratory to the clinic - an abridged historical perspective. Carcinogenesis 17, 1187-1198 https://doi.org/10.1093/carcin/17.6.1187

Hirose H., Sakuma N., Kaji N., Suhara T., Sekijima M., Nojima T., Miyakoshi J. (2006): Phosphorylation and gene expression of p53 are not affected in human cells exposed to $2.1425 \mathrm{GHz}$ band $\mathrm{CW}$ or W-CDMA modulated radiation allocated to mobile radio base stations. Bioelectromagnetics 27, 494-504 https://doi.org/10.1002/bem.20238

Hollstein M., Sidransky D., Vogelstein B., Haris C. C. (1991): p53 mutations in human cancers. Science 253, 49-53 https://doi.org/10.1126/science.1905840

Iijima T., Mishima T., Tohyama M., Akagawa K., Iwao Y. (2003): Mitochondrial membrane potential and intracellular ATP content after transient experimental ischemia in the cultured hippocampal neuron. Neurochem. Int. 43, 263-269 https://doi.org/10.1016/S0197-0186(02)00228-0

Joubert V., Bourthoumieu S., Leveque P., Yardin C. (2008): Apoptosis is induced by radiofrequency fields through the caspase- independent mitochondrial pathway in cortical neurons. Radiat. Res. 169, 38-45 https://doi.org/10.1667/RR1077.1

Kadenbach B., Arnold S., Lee I., Hüttemann M. (2004): The possible role of cytochrome $\mathrm{c}$ oxidase in stress-induced apoptosis and degenerative diseases. Biochim. Biophys. Acta 1655, 400-408 https://doi.org/10.1016/j.bbabio.2003.06.005

Kadenbach B., Ramzan R., Moosdorf R., Vogt S. (2011): The role of mitochondrial membrane potential in ischemic heart failure. Mitochondrion 11, 700-706 https://doi.org/10.1016/j.mito.2011.06.001

Kim R., Emi M., Tanabe K. (2006): Role of mitochondria as the gardens of cell death. Cancer Chemother. Pharmacol. 57, 545-553 https://doi.org/10.1007/s00280-005-0111-7

Merola P., Marino C., Lovisolo G. A., Pinto R., Laconi C., Negroni A. (2006): Proliferation and apoptosis in a neuroblastoma cell line exposed to $900 \mathrm{MHz}$ modulated radiofrequency field. Bioelectromagnetics 27, 164-171 https://doi.org/10.1002/bem.20201

Moquet J., Ainsbury E., Bouffler S., Lloyd D. (2008): Exposure to low level GSM $935 \mathrm{MHZ}$ radiofrequency fields does not induce apoptosis in proliferating or differentiated murine neuroblastoma cells. Radiat. Prot. Dosim. 131, 287-296 https://doi.org/10.1093/rpd/ncn171

Nikolova T., Czyz J., Rolletschek A., Blyszczuk P., Fuchs J., Jovtchev G., Schuderer J., Kuster N., Wobus A. M. (2005): Electromagnetic fields affect transcript levels of apoptosis-related genes in embryonic stem cell-derived neural progenitor cells. FASEB J. 19, 1686-1688 https://doi.org/10.1096/fj.04-3549fje

Oren M., Rotter V. (1999): Introduction: p53-the first twenty years. Cell. Mol. Life Sci. 55, 1-9 https://doi.org/10.1007/s000180050265

Shankar S., Srivastava R. K. (2007): Apoptosis, cell signaling and human diseases. Molecular Mechanisms. Vol. 2, 2nd ed., Humana Press, New Jersey

Skárka L., Ostádal B. (2002): Mitochondrial membrane potential in cardiac myocytes. Physiol. Res. 51, 425-434

Strachan T., Read A. P. (1999): Cancer Genetics. In: Human Molecular Genetics. 2nd ed., Wiley, New York

Struckhoff A. P., Bittman R., Burow M. E., Clejan S., Elliott S., Hammond T., Tang Y., Beckman B. S. (2004): Novel ceramide analogs as potential chemotherapeutic agents in breast cancer. J. Pharmacol. Exp. Ther. 309, 523-532 https://doi.org/10.1124/jpet.103.062760

Vojtěsek B., Lane D. P. (1991): Regulation of p53 protein expression in human breast cancer cell lines. J. Cell Sci. 105, 607-612

Yee K. S., Chen J. S., Chang A. H. (1992): Conformal finite-difference time-domain (FDTD) with overlapping grids. IEEE Trans. Antennas Propag. 40, 1068-1075 https://doi.org/10.1109/8.166532

Yu Q. (2006): Restoring p53-mediated apoptosis in cancer cells: new opportunities for cancer therapy. Drug Resist. Update 9, 19-25 https://doi.org/10.1016/j.drup.2006.03.001

Zeni O., Sannino A., Sarti M., Romeo S., Massa R., Scarfi M. R. (2012): Radiofrequency radiation at $1950 \mathrm{MHz}$ (UMTS) does 
not affect key cellular endpointsin neuron-like PC12 cells. Bioelectromagnetics 33, 497-507

https://doi.org/10.1002/bem.21712

Zou H., Henzel W. J., Liu X., Lutschg A., Wang X. (1997): Apaf-1, a human protein homologous to C. elegans CED-4, participates in cytochrome c-dependent activation of caspase-3. Cell 90, 405-413

https://doi.org/10.1016/S0092-8674(00)80501-2
Zou H., Li Y., Liu X., Wang X. (1999): An APAF-1-cytochrome c multimeric complex is a functional apoptosome that activates procaspase-9. J. Biol. Chem. 274, 11549-11556 https://doi.org/10.1074/jbc.274.17.11549

Received: March 20, 2016

Final version accepted: May 10, 2016

First published online: September 12, 2016 